Izvirni znanstveni članek Original scientific paper (1.01) Besedilo prejeto Received: 20. 9. 2020; Sprejeto Accepted: 28. 10. 2020 UDK $27-277-248.76$

DOI: 10.34291/Edinost/75/02/Marecek (C) 2020 Mareček CC BY 4.0

\title{
Petr Mareček
}

\section{A Crux Interpretum in Jas 4,5}

\author{
Crux Interpretum $v J a k 4,5^{1}$
}

\begin{abstract}
Verse Jas 4,5 poses two problems for exegetes. On the one hand, it is not easy to identify the apparent quotation from Scripture, and on the other hand, it is difficult to determine the meaning of this verse as a whole, as well as each statement in it. This text begins with a rhetorical question (»Or do you think it doesn't make sense what Scripture says?«, Jas $4,5 \mathrm{a}$ ) and is followed by a statement (»He [God] jealously longs for the spirit which [God] dwelt in us «, Jas 4,5b). The statement Jas 4,5b, which is presented as a biblical quote, is not found in the Old Testament or in the surviving unbiblical writings as a literal quote. It is not entirely possible to exclude the option that James cites an unknown work in Jas 4,5b, but it is more likely that he created a biblical quote from various elements of Scripture on the subject of God's jealousy, which is linked to the idea of Israel's chosen people as the bride of their God.
\end{abstract}

Key Words: Biblical exegesis, The Catholic Epistles, The Letter of James, Crux interpretum, The Old Testament

Izvleček: Vrstica Jak 4,5 predstavlja za eksegete dva problema. Po eni strani je ni enostavno prepoznati kot citat iz Svetega pisma, po drugi strani pa je težko določiti pomen tega verza kot celote in vsake izjave v njem. Besedilo se začne z retoričnim vprašanjem ("Ali mislite, da Pismo v prazno pravi?", Jak 4,5a), sledi pa mu izjava ("Bog do ljubosumnosti hrepeni po Duhu, ki ga je naselil v nas", Jak 4,5b) Dobesedne izjave Jak 4,5b, ki je predstavljena kot svetopisemski citat, ne najdemo $v$ Stari zavezi nitiv ohranjenih nebiblijskih spisih. Ni mogoče povsem izključiti možnosti, da Jakob v 4,5b citira neznano delo, zdi pa se verjetnejše, da je iz različnih elementov Svetega pisma ustvaril biblijski citat na temo Božjega ljubosumja, ki je povezano z idejo o izbranem ljudstvu Izraela kot nevesti svojega Boga.

Ključne besede: biblijska eksegeza, pisma, Jakobovo pismo, Crux interpretum, Stara zaveza

1 This study is a result of the research funded by the project IGA_CMTF_2020_005 »Cruces interpretum of the Letter of James«. 


\section{Introduction}

The Letter of James, which has been generally overlooked in the history of the Church, is in many ways a unique work of the New Testament. Although, in terms of discussing socio-ethical doctrine and sociology, it lacks explicit reflections on the suffering, death and resurrection of Jesus Christ, it can be ranked among the most interesting and inspiring books of the New Testament. The Letter of James, which provides instructions for the practical preservation of faith, a wise life, and sympathetic ethics, is considered »one of the most enigmatic writings of the New Testament" (Hartin 2003, 1). Donald A. Hagner even claims that it is "the most puzzling book of the NT/ $(2012,671)$. The Letter of James has caused difficulties for the New Testament researchers for as long as one can remember because it contains a large number of enigmatic textual places (Meyer 1930, 1). One of these places is Jas 4,5, which has been called crux interpretum (De Ambroggi 1949, 64; Konradt 1998, 81; Popkes 2001, 269) and described by many New Testament scholars as one of the most difficult texts in the entire epistle (Burdick 1981, 193; Martin 1988, 149). ${ }^{2}$ It has even been suggested that this may be the most difficult verse in the New Testament (Witherington III 2007, 514). Some researchers who presented their interpretations often felt compelled to admit that "no interpretation is free from problems" (Blomberg and Kamell 2008, 192). It is no surprise that Greek patristic tradition, apart from commentaries and anthologies, does not seem to quote Jas 4,5 even a single time. ${ }^{3}$ The difficulty of interpreting Jas 4,5 is due to two facts: the identification of the apparent quotation of Scripture, and the interpretation of the meaning of Jas 4,5 itself, as it can be argued that in this verse each expression gets its meaning from its relation to the others and the overall context.

The purpose of this article is to offer an interpretation of Jas 4,5 and to identify the »Scripture to which the author of the Letter of James refers. The article is divided into three parts. The first part will discuss the question of the use of different traditions in the Letter of James. The second

2 Moffatt $(1953,59)$ states: "The fifth verse is extremely obscure.« Davids (1982, 162) denotes the verse »one of the thorniest problems in the epistle« Carpenter $(2000,189)$ calls it an »exegetically thorny passage 
part will offer an interpretation of Jas 4,5 within its context. Finally, the third part will try to identify the »Scripture« to which Jas 4,5 refers.

\section{The Use of Various Traditions in James}

With a careful reading of the Letter of James, we can observe that hardly a verse can be found in the work that has no connection with tradition. In the Letter of James we constantly encounter ideas, motives, formulations or words that have their origins in the Old Testament, Jewish tradition, Greco-Roman tradition ${ }^{4}$ and early Christian tradition. ${ }^{5}$ The author of this letter did not only take over material from various traditions, but also compiled it and brought it together. This gives the Letter of James a certain »internationality and interdenominationalism«(Dibelius 1984, 36).

From the Septuagint, which was the Bible of the Letter of James and which influenced its language ${ }^{6}$ its author draws direct quotations, allusions and examples of persons. ${ }^{7}$ However, when he quotes Scripture directly, he always introduces the biblical text using the citation formula. We can see that the Old Testament, as the "Scripture», is referenced three times

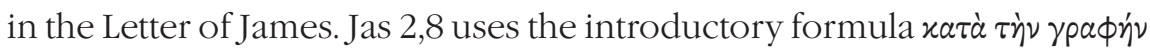
"according to the Scripture « to introduce a verbatim quotation of Lev 19,18, while Jas 4,8 employs the formulation $\delta \grave{\imath} \lambda \dot{\varepsilon}^{\prime} \gamma \varepsilon \iota$ » therefore it says « to introduce a verbatim quotation of Prov 3,34. Jas 2,23 uses the extended formula

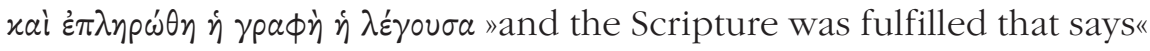
to introduce a quotation of Gen 15,6. In none of the citations does James denote the biblical location of the quotation. He does not even say »in the Law « or something similar. Two of the citations come from the Pentateuch whereas the third quotation is from the Book of Proverbs.

4 In a broader sense, James stands here in the tradition of the »Hellenistic moralists (Malherbe 1992, 267-333).

5 The Letter of James contains a number of expressions reminiscent of Jesus' words as recorded in the Gospel tradition (see further Kloppenborg 2004, 93-141; Schröter 2008, 233-255).

6 Texts Jas 1,1-11; 3,9; 5,4, 7 contain hints of the LXX language. With reference to language and style of the Letter of James see Mußner (1987, 26-33).

7 Barth $(1962,54)$, when discussing the use of the Old Testament in the Epistle to the Hebrews, uses a fourfold distinction: 1) direct quotations, 2) indirect quotations or allusions, 3) summaries or reflections, and 4) references to names and topics. 
Lev 19,18 is quoted a total of 9 times in the New Testament (Matt 5,43; 19,19; Matt 22,39; Mark 12,31, 33; Luke 10,27; Gal 5,14; Rom 13,9; Jas 2,8) and is one of the most frequently used Old Testament texts in the New Testament. In Jas 2,8 as well as in Gal 5,15 and Rom 13,9 it is presented as a summary of the Law. Jas 2,23 is almost a verbatim quotation from Gen 15,6, although James makes some small stylistic alterations. He replaces the conjunction xaí with $\delta$ ' and uses the later form, 'A $\beta$ pá $\mu$, for Abraham, rather than 'A $\beta$ pá $\mu$, which is found in Gen 15,6 LXX and which is more correct, because the name 'A paá $\mu$ is given only in Gen 27,5. These changes could probably be caused by the fact that the author of the Letter of James quoted the Old Testament text from memory without the direct use of a biblical text. (Laws 1973, 211) James adds to the quotation from Gen 15,6 the verbal expression »he was called the friend of God «. The verb in the passive $\varepsilon x \lambda \eta^{\prime} \theta \eta$ "was called « refers to God's action. The honorary title $\phi i$ ì $\circ \theta_{\varepsilon \circ \tilde{u}}$ »friend of God « for Abraham does not appear literally in any biblical text. In early Jewish literature, this title is documented for important Old Testament figures: Moses, Isaac, Jacob, Abraham. ${ }^{8}$ This title could be given to Abraham in the Jewish tradition and can be based on some biblical texts. It is possible to relate Jas 2,23 to the Book of Wisdom, which speaks of wisdom that passes into holy souls and makes them "friends of God (фínous $\theta \varepsilon \circ \tilde{u}$ ), and prophets« (Wis 7,27; 7,14). When the Book of Wisdom speaks of Abraham's trial, it states: „When the nations in wicked agreement had been put to confusion, recognized the righteous man and preserved him blameless before God, and kept him strong in the face of his compassion for his child " (Wis 10,5). So Abraham is a "friend of God" and »righteous", because he lets himself to be guided by God's wisdom and remains faithful in the trial of sacrificing his child. This image of Abraham can be found in some texts of early Jewish literature, where the fear of God spoken of in the biblical account of the sacrifice of Isaac is interpreted as love for God (Gen 22,12). In the Qumran literature we find a testimony about Abraham, who is considered a "friend because he kept the commandment of God and chose not| the will of his own spirit «(CD 4,2-3). The Book of Jubilees states at the end of Abraham's list of trials: »He was found faithful and his soul was not impatient; and he was not slow to act; for

8 In reference to Abraham as a friend of God, see Jub. 19,9; Apoc. Abr. 9,6; 10,6; Test. Abr. B 4,10; 13,1, 6; CD 3.2; Philo, Abr. 273; Migr. 45 (Peterson 1923, 161-202; Stählin 1973, 165-167). 
he was faithful and a lover of the Lord." $(J u b .17,18)$ Finally, early Christian literature testifies to the designation of Abraham as "the friend of God" (1 Clem. 17,2) because of his obedience to the words of God (1 Clem. 10,1). The almost verbatim quotation Prov 3,34 from LXX (xúpıs í $\pi \varepsilon p \eta \phi a ́ v o เ s$

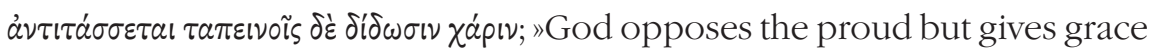
to the humble $)$ in Jas 4,8 is relevant since at that point the LXX differs

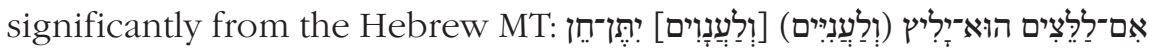
"Toward the scorners he is scornful, but to the humble he shows favour". Moreover, we can see that the wording of the quotation from Prov 3,34, which is given in Jas 4,6 and elsewhere in early Christian literature (1 Pet 5,5; 1 Clem. 30,2; Ign. Eph. 5,3) always with the same difference from LXX (o) Acós instead of xúpıs, may be an indication that it is possibly not a direct quotation from Scripture, but that the text is taken from an early Christian tradition. Lastly, in Jas 2,11, reference is made to the two commandments of the Decalogue - »do not commit adultery, do not kill« - by the theocen-

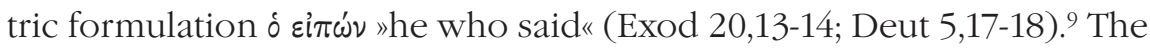
wording of these two commandments from the Decalogue is very close to the LXX text with some minor stylistic improvements. ${ }^{10}$ From the way in which these two commandments from the Decalogue are cited, it is clear that James presupposes readers who have a certain acquaintance with God's gift of the Decalogue to Moses on Sinai, for without this knowledge

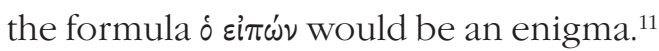

In addition to the above mentioned direct references to the Old Testament, it can be noted that in the Letter of James there are a large number of allusions to texts from the Bible (Lev 19,15 in Jas 2,9; Deut 6,6 in Jas 2,29; Gen 22,1-19 in Jas 2,21-23; Josh 2,1-22 in Jas 2,25; Gen 1,26-28; 9,2 in Jas 3,7; $1 \mathrm{Kgs} 17-18$ in Jas 5,17-18) $)^{12}$ as well as a number of biblical sayings: »like

9 According to Aland et al. (2014, 863), there are four quotations from the Old Testament in the Letter of James: Jas 2,8 (Lev 19,18); Jas 2,11 (Exod 20,13-14; Deut 5,17-18); Jas 2,23 (Gen 15,6); Jas 4,6 (Prov 3,34). By contrast Aland et al. (2012, 694) give additional references to Isa 5,9 in Jas 5,4 and Jer 12,3 in Jas 5,5 in italics and thus consider them to be direct quotations from the Old Testament.

10 James uses the negation $\mu$ ' instead of ou from the LXX.

11 Laws $(1973,212)$ considers the possibility that the author of the Letter of James sis rather calling on a general, perhaps even liturgical, knowledge of the Decalogue independent of the textual tradition «.

12 Many exegetes are considering a larger number of allusions, others a smaller number. For example, Allison, jr. $(2013,51)$ distinguishes four ways of using LXX in the Letter of James. He finds in the letter: 4 quotations/citations (Gen 15,6 in Jas 2,23; Exod 20,13-14 = Deut 5,17-18 in Jas 2,11; Lev 19,18 in Jas 2,8; Prov 3,34 in Jas 4,6), 4 allusions (Lev 19,13; Deut 24,14-15 in Jas 5,4; Lev 19,15 in Jas 2,1, 9; 
a flower of the grass he will pass away« (Jas 1,10-11; Isa 40,7), »the ears of the Lord of hosts« (Jas 5,4; Isa 5,9), »the day of slaughter« (Jas 5,5; Jer 12,3), »he will cover over a multitude of sins « (Jas 5,20; Prov 10,12). (Mayor 1892, lxviii-lxxiii; Cantinant 1973, 17-20; Popkes 1999, 216-218; Carson 2007, 997-1013) Some scholars are of the opinion that Lev 19 is not only quoted in Jas 2,8, but that it appears several times in the background of the text. Luke Timothy Johnson enumerates the following parallels: Lev 19,12 to Jas 5,12; Lev 19,13 to Jas 5,4; Lev 19,15 to Jas 2,1, 9; Lev 19,16 to Jas 4,11; Lev 19,17b to Jas 5,20; Lev 19,18a to Jas 5,9; Lev 19,18b to Jas 2,8 (Johnson 1982, 399). Anthony Tyrrell Hanson limits the relations of Lev 19 to Jas 2,1-8, but includes a parallel between Lev 19,12 and Jas 2,7 (Hanson 1983, 147-155). However, it remains a question of critical assessment how far these allusions go.

The letter of James mentions several Old Testament characters who are characterized by great deeds. Jas 2,21-23 introduces Abraham, who is presented in connection with Isaac as an example of a human being who has been justified by works. In a similar way, Rahab serves as another example of one who was also justified by the work of giving guidance to the messengers. In Jas 5,10»the prophets who spoke in the name of the Lord « are

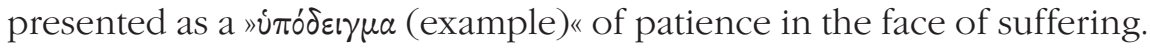
In Jas 5,11 Job is mentioned as an example of perseverance. Finally, in Jas

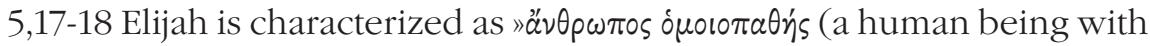
the same nature) as we are " and presented as an example of the effective prayer of a righteous man. His example functions as an encouragement for prayer. None of these Old Testament characters obtains any introduction by James and it is not stated where they appear in Scripture. Elijah is not even called a prophet. James presupposes his readers' knowledge of these personal biblical examples. It can be assumed that James may have been influenced by early Jewish methods of interpretation such as Midrash. Most of the scriptural references occur in Jas 2; the personal biblical examples are also to be found in Jas 2 as well as in the closing text of the epistle (Jas 5,7-20).

Lev 19,15-18 in Jas 4,11-12; Deut 6,4 in Jas 2,19), 13 borrowings (Gen 1,11 in Jas 5,18; Gen 1,26-27 in Jas 3,7-9; Isa 5,7-9 in Jas 5,4; Isa 32,15-20 in Jas 3,18; Isa 40,6-7 in Jas 1,9-11; Jer 5,24 in Jas 5,7; Jer 12,3 in Jas 5,5; Ezek 33-34 in Jas 5,19-20; Hos 14,10 in Jas 3,13; Prov 10,12 [non-LXX form] in Jas 5,20; Wis 2 in Jas 4,13-5,6; Eccl 2 in Jas 5,10; Eccl 15,11-12 in Jas 1,13) and 4 summaries of episode (Gen 22,1-19 in Jas 2,21-23; Josh 2,1-22 in Jas 2,25; 1 Kgs 17-18 in Jas 5,17-18; the book of Job in Jas 5,11). 
The letter of James was also inspired by the deuterocanonical books of the Old Testament. One can notice the similarities between the Letter of James and "Sapiential Books«: the Book of Wisdom and Sirach (Ecclesiasticus). In the Letter of James we can find a number of indirect references to the Book of Wisdom (Wis 1,11 in Jas 4,11; 5,9; Wis 2,1-2, 4; 5,14 in Jas 4,14; Wis 2,10-20 in Jas 5,1, 6; Wis 7,7; 9,6 in Jas 1,5). We can also discover many allusions to Sirach (Sir 3,17 in Jas 3,13; Sir 4,29; 5,11 in Jas 1,19; Sir 7,10 in Jas 1,6; Sir 10,22 in Jas 1,9-10; Sir 15,11-20 in Jas 1,13-15; Sir 18,15; 20,15 in Jas 1,5; Sir 19,16 in Jas 3,2; Sir 29,10-11 in Jas 5,2 etc.) (deSilva 2012, 58-85). ${ }^{13}$ It seems that the author of the Letter of James knew these books, although he did not cite them as Scripture and did not clarify the references to them. It can be observed that many hapax legomena in the Letter of James originate from the wisdom books in LXX. ${ }^{14}$ No other New Testament book was influenced more significantly by the wisdom tradition than the Letter of James (von Lips 1990, 434; Schnelle 2002, 439).

However, the Letter of James also shows knowledge and use of other early Jewish literature. It can be seen that the presentation of the Old Testament characters, especially those mentioned here, are influenced by this literature. Jas 2,21-23 is an update of the early Jewish tradition about Abraham (Sir 44,20; 1 Macc 2,52). The statement about Job's perseverance in James 5,11 refers less to the canonical book of Job than to the early Jewish haggadah about Job (T. Job). The social critique of the Letter of James (especially Jas 5,1-6) points to the influence of the prophetic-apocalyptic tradition. The chronology »three years and six months (Jas 5,17), which is mentioned in connection with Elijah, does not appear anywhere in the Old Testament, but we encounter it in tradition (especially in Luke 4,25-26). Knowledge of early Jewish literature is noticeable, but it is never clearly pointed out. ${ }^{15}$

13 Frankemölle (1994, 85-86) argues that the Letter of James not only shows a theological and anthropological similarity, but that it is literally dependent on the Book of Sirach and that the Letter of James is presented as a re-reading of this book. On the other hand, Popkes $(2004,149)$ states that neither the structure nor the subject matter nor can the scope of the Letter of James be explained from the Book of Sirach.

14 According to Halson (1968, 308-309), the Letter of James contains 67 NT hapax legomena, 52 of which are Septuagintal. Of those, 34 appear in the wisdom literature, 15 in the Pentateuch, 12 in the historical books, 9 in the Psalms, 18 in the Latter Prophets and Daniel, and 25 in non-wisdom apocryphal books. Based on these statistics, he concludes that »in his distinctive vocabulary [...] James has a marked predilection for words from the Septuagintal Wisdom literature».

15 In reference to the Use of the Old Testament and the Jewish Tradition in the Letter of James, see Bauckham (1988, 306-309). 
Parallels with the non-biblical literature of early Judaism - Avot, Let. Aris., 4 Macc, Ps.-Phoc. (Bottini 1986, 171-181), Philo, ${ }^{16}$ T. 12 Patr. ${ }^{17}$ Qumran manuscripts $^{18}$ - are often mentioned in the commentaries. However, the parallels are not sufficient to prove literary dependence. It is usually assumed that the Letter of James drew from the same current of Hellenistic-Jewish tradition. Lexical and thematic similarities between the Letter of James and the texts from the Jewish tradition can be explained with reference to a common religious and cultural background. Since in the Letter of James these same expressions and themes are placed in a different context and hold a different function, it is necessary to exclude the literary dependence of this letter on the above-mentioned writings that come from the Jewish environment. From this it is clear that James drew on a rich tradition originating mainly from the Jewish environment, which he did not receive as a literary work, but he knew it from the traditional lived piety of Judaism.

\section{The Meaning of James 4,5}

James 4,5 is part of the narrative unit that relates to the theme "struggles and quarrels among the members of the Christian community « (Jas 4,110) and that can be divided into three parts on the basis of caesuras in the text (Schnider 1987, 97; Bottini 2014, 160). The first part (Jas 4,1-3) deals with the anthropological causes of conflicts in the Christian community. The second part (Jas 4,4-6), using two references from the Scripture, points to the incompatibility of love for the world and friendship with God. The last, third part (Jas 4,7-10) deduces (oũv »therefore «) from the quotation from Scripture (Jas 4,6b) what needs to be done in order for human being to behave properly before God. We can see that our text

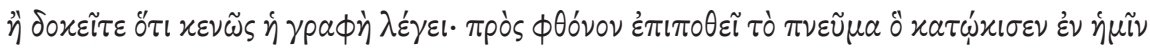

16 Frankemölle $(1994,86)$ reckons that the author of the Letter of James was influenced by the work of Philo of Alexandria.

17 Konradt (1998, 179-194) on the example of the commandment to love one's neighbour, points to both the similarities and the differences between the Letter of James and the text of the Testaments of the Twelve Patriarchs.

18 Verseput $(1998,691-707)$ compares the fragmentary text from Qumran with Jas 1,1-18 and points out the thematic and structural similarities between the two texts, but also notes the mutual differences that stem from the literary type of James' work, which is "a letter of comfort and instruction for Christian communities in the diaspora" (707). 
(Jas 4,5) ${ }^{19}$ together with the following verse serves as a justification for the statement: "friendship with the world is enmity with God « (Jas 4,4). What does this statement in Jas 4,5 mean by itself and in context?

In terms of textual criticism, Jas 4,5 contains two problematic places, which are not of a fundamental nature. The word $\phi$ óvov is replaced by $\phi$ óvov in the two minuscule manuscripts from the $11^{\text {th }}(1243)$ and $14^{\text {th }}$ (2492) centuries. Secondly, the textual reading $x a \tau \dot{\omega}$ xเ

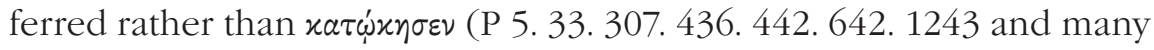
others).$^{20}$ Two separate verbs are attested: $x a \tau o x i \xi \omega$ "place in, cause to live in«, which is a hapax legomenon in the New Testament and occurs only

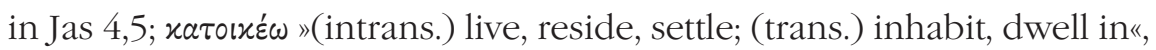
which is more common in the New Testament (a total of 44 occurrences).

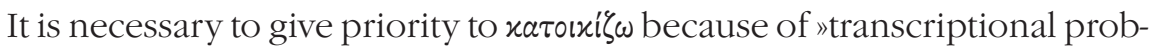
ability« (Metzger 2000, 612) by which the more complicated reading can

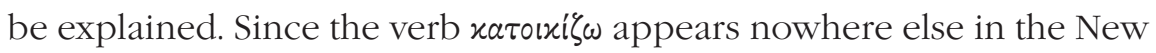
Testament it is more likely that copyists would have substituted it with the

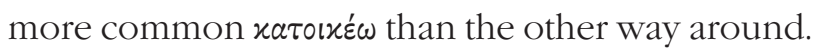

The difficulty of understanding verse Jas 4,5 has led some scholars to believe that the original text was rendered incomprehensible by damage, and they have made suggestions for conjectural emendation. In 1730 a Swiss theologian, known as a New Testament critic, Johann Jakob Wettstein proposed a conjecture which would emend the text so that in-

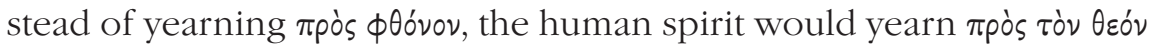
(Wettstein 1730, 172). This conjecture was also shared by Otto Kirn (1904, $131-133)^{21}$ and Clemens Könnecke $(1908,15)$. Nowadays, this conjecture

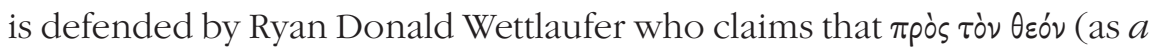

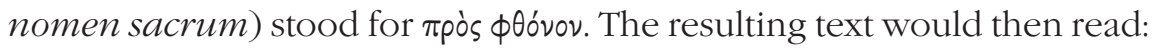
"Do you think that in vain the scripture says 'the spirit he caused to dwell within us yearns for God,' with Eccl 12,7 and Ps 41,2 (LXX) as the source text (Wettlaufer 2013, 148-157). Another conjecture was proposed by J. A. Findlay who reads фóvov for $\phi$ tóvov in accordance with two minuscule

\footnotetext{
19 The wording of the Greek text is in accordance with the critical edition Aland et al. (2012, 692).

20 Aland et al. 2012, 692.

21 Discussed in more detail in Kirn (1904, 593-604).
} 
manuscripts dating from the $11^{\text {th }}$ and $14^{\text {th }}$ centuries and who translates the verse: "the spirit that took up its abode in you (when your contentions began) is yearning for murder, but he gives greater grace». Findlay regards it as free reference to Gen 4,7, which addresses Cain the murderer: "If you do well, will you not be accepted? And if you do not do well, sin is lurking at the door; its desire is for you, but you must master it." (Findlay 1925-1926, 381-382) Finally it needs to be mentioned that Haire A. Forster

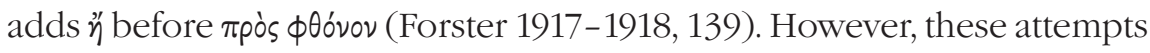
are unpersuasive and are no longer relevant today.

The trouble with the meaning of Jas 4,5 is caused by several interrelated syntactical and lexical ambiguities. A number of questions arise in connection with the interpretation of Jas 4,5. First of all, it is possible to ask: where does the quotation begin and end? Wilhelm Martin Leberecht de Wette suggested that Jas 4,5a does not constitute an introduction to the quotation, but clarifies the previous verse Jas 4,4, which contains the motives of the New Testament tradition (2 Pet 3,15-16; 1 Tim 5,18), which we encounter in 1 John 2,15; Matt 6,7; Luke 16,13 and Rom 8,7 (de Wette 1853, 238). This

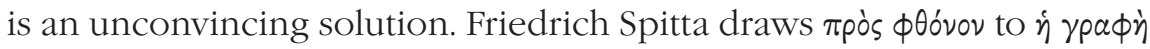
$\lambda \varepsilon \dot{\gamma \varepsilon l}$ as a thematic datum: "Scripture says about envy." (Spittta 1896, 118 and 120) But a thematic datum $\pi$ ós with accusative "what concerns« is not expected in an introduction to the biblical quotation. The preposition $\pi \varepsilon p^{\prime}$ with genitive would be more common (Burchard 2000, 172-173). August

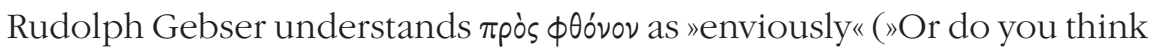
that the Scripture speaks to no purpose, enviously «), and regards the following words Jas 4,5b-6a as a parenthesis or preliminary interpretation of the quotation from Jas 4,6b (Gebster 1828, 344-345; also Carpenter 2000, 199-204; Wypadlo 2006, 123-125; McCartney 2009, 216-217). ${ }^{22}$ Such an understanding of the text is unpersuasive for the reason that we are facing the unbearable clash of »enviously« and »to no purpose«. Furthermore, Jas 4,5a lets us expect a threatening word rather than a promise as in Jas 4,6b. According to Wiard Popkes, James became confused. He originally wanted immediately to quote Prov 3,34, but inadvertently continued with Jas 4,5b, which still belongs to Jas 4,1-4 (Popkes 1997, 99-103; 1999,

22 McKnight (2011, 336-337 and 340-341) sees the paraphrase of Prov 3,34 in Jas 4,5b-6a and quotation of Prov 3,34 in Jas 4,6b. 
224-227). Such an understanding of the text is too complicated and also implausible. The most appropriate understanding of the Greek text seems to take $\pi \rho o ̀ s ~ \phi \theta o ́ v o v$ as modifying $\dot{\varepsilon} \pi \iota \pi 0 \theta \varepsilon \tilde{l}$, since on the one hand $\lambda \dot{\varepsilon} \gamma \varepsilon l$ is already modified by $\varkappa \varepsilon v \tilde{\omega} \varsigma$ and on the other hand $\dot{\varepsilon} \pi \iota \pi \circ \theta \varepsilon \tilde{\imath}$ would lack a more specific determination: the longing for whom, for what. The quotation begins where you would expect it, after $\dot{\eta} \gamma \rho a \phi \dot{\eta} \lambda \dot{\varepsilon}^{\prime} \varepsilon$.

James 4,5 starts with a rhetorical question that has an almost provocative

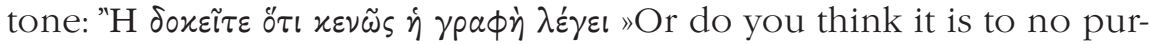
pose that the Scripture says?" (Jas 4,5a) With this interrogative sentence that calls for agreement (Matt 12,29; 1 Cor 6,16), the author of the Letter of James urges his readers to acknowledge the unconditional validity

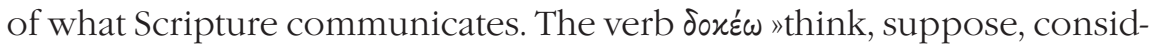
er "states, as in James 1,26, the wrong opinion, ${ }^{23}$ and therefore implies the answer: »No, the Scriptures do not say in vain." The adverb $x \varepsilon v \tilde{\omega} s$ »in vain, unnecessarily, to no purpose «, which appears in the New Testament only in Jas 4,5 and in LXX only in Isa 49,4, here means »only with empty words/ to no purpose ${ }^{24}{ }^{24}$ The expression $\dot{\eta} \gamma$ pa $\phi \dot{\eta} \lambda \dot{\varepsilon} \gamma \varepsilon$ is a formula that introduces the citation of a biblical text in the Corpus Paulinum 6 times (Rom 4,3; 9,17; 10,11; 11,2; Gal 4,30; 1 Tim 5,18), where in three cases (Rom 4,3; 11,2; Gal 4,30) it introduces an interrogative sentence, as in James 4,5a. It is preferable to understand $\dot{\eta} \gamma$ pa $\phi \dot{\eta}$ as "passage of Scripture« (Davids 1982, 162; Hartin 2003, 199) rather than "Scripture as such" (contrary to Johnson 1995, 280).

What follows is a statement, not a second rhetorical question along with Jas $4,5 \mathrm{a} \cdot{ }^{26}$ The quotation that is included in the question ends after $\dot{\varepsilon} \nu \dot{\eta} \mu \tilde{\nu}$

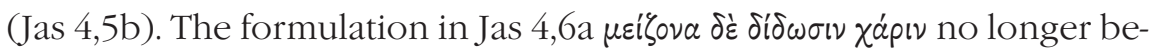
longs to the quotation because of the adversative particle $\delta \dot{\varepsilon}$ that creates

23 Mark 6,49; Luke 12,51; 13,2, 4; 24,37; 1 Cor 3,18; 8,2; 10,12; 14,37.

24 Balz (1981, col. 699): "daß die Schrift nur mit leeren Worten / umsonst spricht".

25 Also John $7,38.42 ; 19,37$

26 Some scholars regard Jas 4,5 as two questions. The term $\lambda \varepsilon \dot{\varepsilon} \varepsilon$ is understood in the sense of "speak«: "Do you suppose that the Scripture speaks in vain? Does the spirit which he made to dwell in us long jealously (or enviously)? (Laws 1973, 210-215; 1980, 174-179; Johnson 1995, 280; Penner 1996, 152; Wall 1997, 202; Sleeper 1998, 109; Varner 2014, 421-422). However, if Jas 4,5b was intended as a rhetorical question (with a negative answer), it would have to be started with $\mu$ ' (Blass - Debrunner Rehkopf 1990, § 427). 
a sharp contrast with the previous text, but is rather a new sentence that James formulated independently by using the last three words of Prov 3,34 in preparation for the biblical quotation in Jas 4,6b. The question mark should not be placed behind Jas 4,6a, ${ }^{27}$ but behind Jas 4,5. Moreover, the

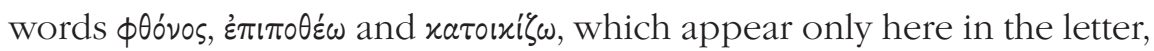
and which possibly have the metre, the rhythmic pattern that is typical of epic poetry, ${ }^{28}$ speak in favour of a quotation in Jas 4,5b.

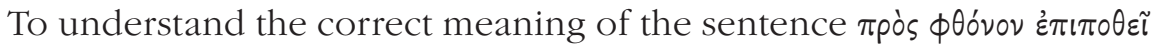

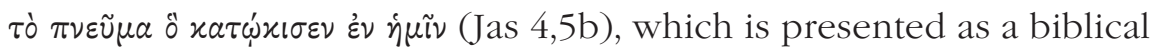
quotation, it is necessary to answer some controversial questions. Is the subject of the verb عं $\pi \iota \pi \circ \theta \varepsilon \tilde{\imath}$ God or spirit? And similarly, is the subject of the

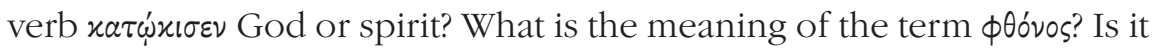
possible to understand it as "envy« or »jealousy«? Does the expression $\pi \nu \varepsilon \tilde{\mu} \mu a$ relate to the divine or human spirit? There are basically two possible interpretations with variations.

The first interpretation takes $\pi \nu \varepsilon \tilde{u} \mu \alpha$, namely the human mind, to be in the

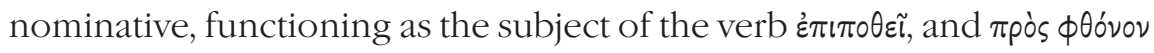
is to be understood negatively as »envious «. The reading of the text therefore is: "The (human) spirit that he (God) made dwell in us yearns enviously."(Chaine 1927, 101-103; Michl 1963, 168-171; Mitton 1966, 155-156; Adamson 1976, 171-173; Laws 1980, 177-178; Prockter 1989, 625-627; Johnson 1995, 280-282; Richardson 1997, 177; Burchard 2000, 171-174; Hartin 2003, 200; Fabris 2004, 279-281; Maier 2004, 183; McKnight 2011, 338; Painter 2012, 140). In this rendering $\pi \nu \varepsilon \tilde{\mu} \mu \alpha$ is identified with the "spirit« breathed into the human being by God at creation (Gen 2,7). The author of the Letter of James would then be making a point about the human inclination to be envious and jealous. The first part of the quotation proves Jas 4,1-3, namely that the human mind strives enviously for what it does not have. In favour of this interpretation it can be stated that a close examination of the Greek phrase $\pi \rho$ òs $\phi \theta o ́ v o v ~ \varepsilon ̇ \pi ı ० \theta \varepsilon \tilde{~ s h o w s ~ t h a t ~ i t ~ w o u l d ~}$

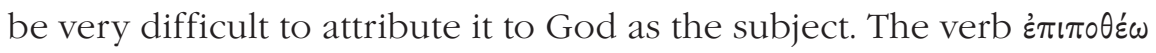

27 Thus erroneously Barbara Aland et al. (2012, 692).

28 Windisch and Preisker (1951, 27), Schneider (1961, 28), Michl (1963, 172-173), Reicke (1964, 46), Assaël and Cuvillier $(2013,231)$ and others suppose a hexameter (Jas 1,17a), which, however, has shortcomings (Blass - Debrunner - Rehkopf 1990, § 487,6). 
which appears with mpós in LXX Ps 41,2, means »strongly desire, long for, feel tender affection for and the subject of it is usually a human being (LXX Deut 13,9; Ps 83,3; 119,20; 174). Only in LXX Deut 32,11 and Jer 13,14, is God the subject of this verb. Moreover, in the Greek Bible, the noun $\phi \theta$ óvos always has a negative connotation and is used in reference to a vice. ${ }^{29}$ All this argues for the spirit as being the subject of the verb, rather than God: »the spirit yearns enviously«. This interpretation is not without substance, however none of the arguments presented is decisive.

According to the second better interpretation, God is the subject of the sentence. It takes $\pi \nu \varepsilon \tilde{v} \mu \alpha$ to be in the accusative case, functioning as the

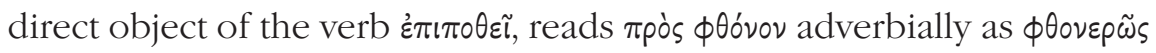
"jealously«(Blass - Debrunner - Rehkopf 1990, \239, n. 8) and positively of God's zeal, that is: »He (God) jealously longs for the spirit that he

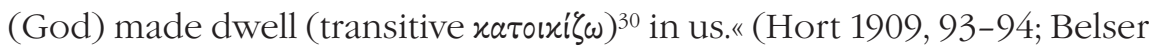
1909, 164-165; Ropes 1916, 264-265; Schlatter 1932, 248-252; Marty 1935, 159-160; De Ambroggi 1949, 64-65; Moffat 1953, 60-61; Tasker 1956, 91 ; Jeremias 1959, 445; Hoppe 1977, 11; Davids 1982, 164; Dibelius 1984, 264-268; Vouga 1984, 117; Mußner 1987, 181-182; Schnider 1987, 101-102; Ruckstuhl 1988, 26; Spicq 1991, 569; Schrage 1993, 45-46; Frankemölle 1994, 602-605; Klein 1995, 112-115; Carpenter 2000, 191-197; Carson 2007, 1006-1007; Witherington III 2007, 514-515; Blomberg and Kamell 2008, 191-192; Moo 2009, 149-151; Assaël and Cuvillier 2013, 232) 31 $^{31}$ This interpretation should be preferred for several reasons. The context indicates that the subject of the sentence in Jas 4,5b is God. Since in the following text God is the subject in both sentences in Jas 4,6, in the first unspoken, in the second (also in the quotation of Scripture) explicit, God must also be the subject in the first »quotation«. In addition, the previous verse Jas 4,4 places God in opposition to the word »world« and each time uses the term God at the end of both sentences of the verse. Based on this fact, God can be an unspoken subject of the verb form $\dot{\varepsilon} \pi \iota \pi \circ \theta \varepsilon \tilde{\imath}$ »he yearns«

291 Macc 8,16; 3 Macc 6,7; Wis 2,24; 6,23; Matt 27,18; Mark 15,10; Rom 1,29; Gal 5,21; Phil 1,15; 1 Tim 6,4; Tit 3,3; 1 Pet 2,1. Ep. Arist. 224; T. Sim. 2,13; 3,1, 2, 4, 6; 4,5, 7; 6,2; T. Dan 2,5; T. Gad 4,5; T. Jos. 1,3, 7; 10,3; T. Benj. 7,2, 5; 8,1; Sib. Or. 3,377, 662; Philo, Fug. 154; Mos. 1,2; Josephus, Ant. 2,1; etc.

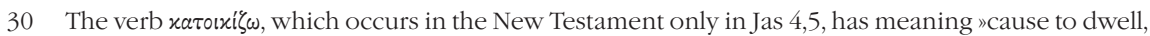
establish, settle«. In early Christian literature it appears in Herm. Man. 3,1 (God caused the Spirit "to dwell in flesh«) (Danker 2000, 535).

31 Martin $(1988,140)$ translates Jas 4,5b »the Spirit God made to dwell in us opposes envy«. 
(New Revised Standard Version Bible complements »God «). Finally, the image used for God's relationship to human beings as a marital union in Jas 4,4 allows the idea of God's jealousy, which often appears in the Old Testament (Exod 20,5; 34,14; Deut 4,44; 5,9; 6,15; Josh 24,19; Isa 9,6). It is necessary to mention that the Septuagint uses the term $\zeta \tilde{\eta} \lambda$ os and not $\phi$ Oóvos. In the Septuagint the expression $\phi$ Oóvos is nowhere associated with

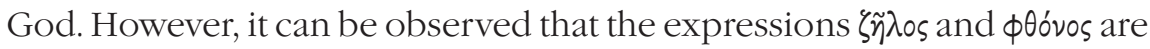
closely related to each other and are sometimes interchangeable (1 Mac 8,16; T. Sim. 4,5; T. Gad. 7,2; 1 Clem. 3,2; 4,7; 5,2), e.g. in the moral discussion of Hellenistic-Jewish writings (Johnson 1983, 335). Furthermore, ф†óvos was sometimes used by Greek writers for the jealousy of the Olympian gods (Moo 2009, 150). By virtue of this fact it can be assumed that the author of James, as a Hellenistic-Jewish writer, also understands the term ф0óvos in the sense of "jealous « and uses it for God..$^{32}$ Perhaps in Jas 4,5 the word

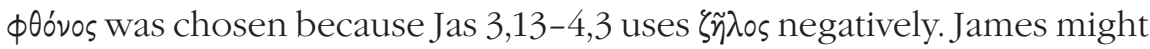
employ $\phi$ Oóvos deliberately as a synonym that has not yet been used. The formulation $\pi$ pòs $\phi$ Oóvov is understood as a rule adverbially in meaning

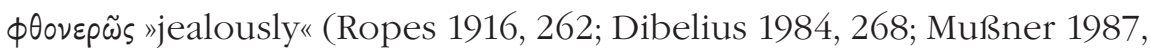
181). After all, the suitability of a reference to God's jealousy for his people in this context prevails over the undisputed linguistic trouble posed by $\phi$ óvos. James 4,5 lucidly gives reason for a point made in the preceding verse Jas 4,4 . The connection of $\phi$ tóvos with a human susceptibility to jealousy seems awkward in this context, but to see in verse Jas 4,5 a reminder of God's desire that his people be completely and unconditionally his provides a beautifully appropriate justification for warning against flirting with the views and the values of the world in verse Jas 4,4. With reference to the verb $\dot{\varepsilon} \pi \imath \pi 00 \dot{\varepsilon} \omega$ »yearn, desire«, it is true that it never refers to God in biblical Greek. But we can observe that it always has a positive connotation in the New Testament..$^{33}$ It seems much more natural to ascribe both verbs in Jas 4,5b to the same subject, in which case »God « must

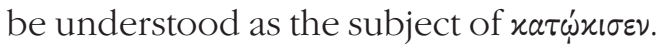

Finally, the question arises of how to understand the term $\pi \nu \varepsilon \tilde{u} \mu \alpha$ spirit«. Is it the Holy Spirit as a gift of grace given at baptism? (Mayor 1892, 132)

32 So do many translations, Frankemölle (1994, 572) and Schnider (1987, 97).

33 Rom 1,11; 2 Cor 5,2; 9,14; Phil 1,8; 2,26; 1 Thess 3,6; 2 Tim 1,4 2 Pet 2,2. 
Or is the spirit meant to be the breath of life in a human being in accordance with the account about creation (Gen 2,7) (Hauck 1926, 197)? Is the $\pi \nu \varepsilon \tilde{u} \mu a$ a gift of prophetic inspiration (Spitta 1896, 120) or God's wisdom (LXX Exod 31,3; 35,31; Deut 34,9; Isa 11,2)? (Hoppe 1989, 91; McCartney 2009, 214-215) Is it a human spirit full of envy? (Michl 1968, 53) Or is it an evil inclination which seems to derive from a central source such as the devil (T. Naph. 8,4) or Satan (T. Dan 6,1-2) (Prockter 1989, 625-627; Johnson 1995, 281; Tsuji 1997, 85-86)? To properly understand the term $\pi \nu \varepsilon \tilde{u} \mu$, it is necessary to take into account the overall wording of the sentence in Jas 4,5b. However, on the basis of the phrase "greater is the grace he gives«, which is found in the following sentence (Jas 4,6a), it is hardly possible to understand $\pi v \varepsilon \tilde{u} \mu a$ in the sense of the Holy Spirit. How could an even "greater" gift of grace beside him be possible or conceivable? It must be added that if the sentence were to be seen to refer to the Holy Spirit, it would be the only such reference in the Letter of James. According to Gen 2,7 at the creation of the first human being, God breathed spirit into him as the breath of life. The Book of Wisdom declares about the spirit of God: »Your incorruptible spirit is in all things." (Wis 12,1) In late Judaism we repeatedly meet the conviction that the spirit of God dwells in this way from the creation of human beings (T. Naph. Heb. 10,9). (Mußner 1987, 182) According to Job 14,15: "God longs for the work of his hands." According to Apoc. Mos. 31, God will seek his vessel, which he created. The author of the Letter of James is of the opinion that the spirit is a gift from God, who is "put in us«. God has bestowed each human being with the breath of life at the creation and, according to James, God jealously longs for this spirit (Schnider 1987, 101-102; Ruckstuhl 1988, 26; Frankemölle 1994, 602-605; Witherington III 2007, 514-515; Blomberg and Kamell 2008, 191-192). ${ }^{34}$ This reading is also supported by the fact that $\pi \nu \varepsilon \tilde{u} \mu \alpha$ in the Letter of James never means the divine, but rather the human spirit as something created by God. Because God is like this and thus manifests himself, he will not tolerate any »friendship with the world « (Jas 4,4). He claims the spirit of human being for himself. The verse Jas 4,5 explains the earnestness of any flirtation with the world by bringing to mind the

34 There are a number of authors according to whom the subject of the sentence is "spirit " and who hold the wording of the text: "the spirit, that God made to dwell in us yearn enviously«. See Burchard (2000, 171-174), Popkes (2001, 269); Hartin (2003, 200), Fabris (2004, 280-281) and Metzner (2017, 226). 
jealousy of the Lord, who requests a total, unconditional, unshakeable loyalty from the people with whom he has united himself.

\section{Identifying the Scripture « to which James $4,5 \mathrm{~b}$ refers}

In the first part of our article, we pointed out the fact that the Letter of James draws on a rich tradition originating mainly from the Jewish environment and that the quotations from the Old Testament are usually preceded by introductory formula. The formulation found in Jas 4,5, $\dot{\eta} \gamma p a \phi \dot{\eta} \lambda \varepsilon^{\prime} \varepsilon \varepsilon$, is undeniably an introductory formula and is found verbatim in several other New Testament texts. ${ }^{35}$ We can observe that in every other case where we find $\dot{\eta} \gamma \rho a \phi \dot{\eta} \lambda \varepsilon \dot{\gamma} \varepsilon \mathrm{i}$ in the New Testament this formula introduces a direct quotation from Scripture or an allusion. The same is true of the Letter of James. Based on this fact, the verse of Jas 4,5 should contain a formal quotation. ${ }^{36}$ It is possible to claim that when James quotes the passage as "Scripture«, he quotes it from the Septuagint and quotes it with precision. $\mathrm{A}$ »free« citation or alternative translation of the Hebrew text would be atypical of him. However, the text of James 4,5b, which the author of the Letter of James states as a biblical quotation, is not found as a literal quotation in the Old Testament or in the preserved non-biblical writings. The origin of the quote is unclear.

Some commentators (F. H. Kern) assume that the words following $\dot{\eta} \gamma$ pa $\phi \dot{\eta}$ $\lambda \varepsilon \dot{\gamma \varepsilon \iota ~(J a s ~ 4,5) ~ u p ~ t o ~ \delta ı ́ ~(J a s ~ 4,6) ~ a r e ~ p a r e n t h e t i c, ~ a n d ~ t h a t ~ J a m e s ~ i s ~ a l r e a d y ~}$ referring to the quotation from Prov 3,34 which is found in Jas 4,6 (see further Mayor 1892, 131). But there seems to be no foundation for such a sudden interruption. Such an opinion that sees a verse Jas 4,5 as an aside must be rejected, since Prov 3,34 would then be furnished with a double introduction. According to Sophie Laws, our text does not quote but alludes to LXX Ps 41,2 or (more likely) 83,3, where the human spirit ( $\left.\psi v \times \eta^{\prime}\right)$ longs ( $\dot{\varepsilon} \pi \imath \circ \bullet \varepsilon \tilde{\imath})$ for God. James is asking rhetorical questions: Is scripture

\footnotetext{
35 See Rom 4,3; 9,17; 10,11; 1 Tim 5,18.

36 Dibelius (1984, 265) says: »Man wird darum, wie es fast alle neueren Interpreten tun, anerkennen müssen, daß auch v. 5 ein Zitat enthält." On the other hand Blomberg and Kamell (2008, 191) argue that "the majority of commentators, therefore, understand v. 5 b to reflect the quotation of 'Scripture', however allusive (and elusive)!
} 
meaningless? (Jas 4,5a) Is this (according to scripture) the proper manner of the soul's desire? (Jas 4,5b) The reply implied if the allusion is taken has to be: Surely not! (Laws 1973, 210-215) Henry Alford sees in Jas 4,5b a loose citation of Deut 32,10-11, where we find a statement about the jealous desire of the Lord over his people (Alford 1864, 314). Arnold Meyer finds in our text a "midrashic paraphrase" of Gen 49,19 (Meyer 1930, 259). Ben Witherington assumes that it can be a general allusion to Gen 6,3-7 and Exod 20,5 used in a midrashic way (Witherington III 2007, 514). Lewis J. Prockter supposes it is a wisdom Midrash on the Noah story: Noah as an example of a »friend of God « who resists evil envy (Prockter 1989, 625627). According to Honoratus Coppieters Jas 4,5 modifies LXX Eccl 4,4: "And I saw all labour, and all the diligent work, that this is a man's envy

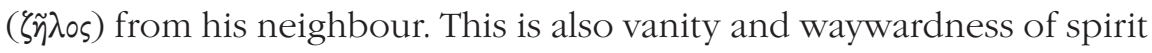

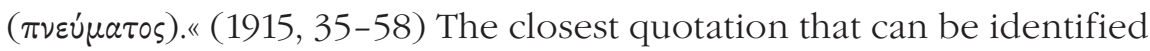
in the Holy Scriptures is from Exod 20,5 (»for I the Lord your God am a jealous God «). ${ }^{37}$ François Vouga believes that James himself wrote with some precision something that could be a summary of the Old Testament law or the first commandment (Exod 20,5 / Deut 5,9) (Vouga 1984, 116). Among the exegetes, the opinion emerged that the sentence in Jas 4,5b can be explained as an inaccurate quotation or a gist of such passages as Exod 20,5 and 34,14 (Burdick 1981, 194). ${ }^{38}$ These views are opposed with the presence of the citation formula $\dot{\eta} \gamma \rho a \phi \dot{\eta} \lambda \dot{\varepsilon} \gamma \varepsilon$. It has been proposed that we are dealing with a Jewish-Hellenistic didactic poem (Hauck 1947, 27; Windisch and Preisker 1951, 27; Schneider 1961, 28; Michl 1963, 172-174) ${ }^{39}$ or with Midrash (Schneckenburger 1832, 95). ${ }^{40}$ Johann Albrecht Bengel finds a quotation not from the Old Testament but the New Testament. For him, James is referring either to Gal 5,17 or 1 Pet 2,1-2, $5(1759,1112)$. Some researchers have assumed that, due to the mention of jealousy, there is a reference to the lost book of Eldad and Modad, named after the two characters in Num 11,24-29 (Herm. Vis. 2, 3, 4) (Spitta 1896, 121; Moffatt 1953, 60; Sidebottom 1967, 52-53; Bauckham 2004, 270-281; Allison 2011,

37 Ropes (1916, 262) identifies James's quotation as possibly a "poetical rendering of the idea of Ex 20«.

38 Nyustrom $(1997,227)$ believes that we have a free paraphrase of Ex 34,14 or that the author of the letter summarizes many Old Testament passages that speak of God's jealousy.

39 Dibelius $(1984,266)$ talks about »ein apokryphes als heilig geltendes Buch».

40 Grimm $(1854,956)$ suggests that James erroneously remembered a Midrash or Targum on some verse as though it were from the Bible itself. 
99-131; 2013, 617-622). Could James be referring to an apocryphal work that he considered Scripture in the way in which Jude quotes from the Assumption of Moses and the book of Enoch (Jude 9 and 14-15 respectively)? Are we dealing here with a quote from an unknown lost work that was considered sacred in the environment of the origin of the Letter of James, but which is now unknown to us (Ewald 1870, 21; Hauck 1926, 196; Grünzweig 1973, 131; Kugelman 1980, 49; Dibelius 1984, 266; Mußner 1987, 183-184; Hoppe 1989, 91; Schrage 1993, 45; Heckel 2019, 60)? ${ }^{\text {?1 }}$ Since quotations of unknown origin that are supposed to be a word of Sacred Scripture can be found in early Christian times ${ }^{42}$ this possibility cannot be wholly ruled out.

We can likewise ask such questions as: Was this a well-known expression circulating among people whom the author of the Letter of James had mistakenly considered to be using a word of Scripture? ${ }^{43}$ Did he take this text from the »card index « of fragmentary passages, which also appear in 1 Peter 5, without knowing that it was not the text of Scripture (Popkes 2001, 271; Idem, 1999, 224-227)? Should we think of a prophecy that arose in Christianity that would have been promoted by labelling it $\gamma \rho \alpha \phi \eta^{\prime}$ and thereby giving it the same origin and the same authority as the Old Testament scriptures? (Schlatter 1932, 248) Is it a paraphrase of an excerpt from Scripture or a reference to a biblical theme (»envy, evil desires«: Gen 4,$7 ; 6,5 ; 8,21$; »jealousy of God«: Ex 20,5, 34,14; Deut 5,9; »the desire of the soul«: Psalm 42,3, 84,3, 119,20) or does James have in mind several Old Testament texts (Jer 3,1-11; Ezek 16; Hos 2,3), which he summarized into one short pregnant form, or does he refer to the message of the entire Bible, which he presents as the word of Scripture (7,38)? (Plumptre 1909, 91; Belser 1909, 165; Tasker 1956, 91; Mitton 1966, 154; Nystrom 1997, 227; Farley 2008, 46; Moo 2009, 150-151)

We can observe in the New Testament that sometimes the singular "Scripture says« refers to a theme rather than to a specific quotation (John

41 Painter $(2012,140)$ states: „We are faced with accepting an unknown reference indicated by 'Scripture says/speaks.'"

42 Matt 2,23; John 7,38; 1 Cor 2,9; 9,10; 2 Cor 4,6; Eph 5,14; 1 Tim 5,18; 1 Clem. 46,2; 1 Clem. 23,3; 2 Clem. 11,2 .

43 Brosend II $(2004,114)$ supposes that this is an otherwise unknown statement of Jesus. 
7,37-39; possibly Matt 2,23). So, most likely, here: the God of the Bible is a jealous God, a point founded not only in the Decalogue but also in many other passages, perhaps most movingly in the prophecy of Hosea. For this reason, then, the English Standard Version, for example, and the New Revised Standard Version were ill-considered when using direct quotation marks. In the Greek text there is no orthographically unequivocal differentiation between a direct citation and an indirect citation, and in our context it would be prudent to give preference to the latter, because the former, with its quotations marks, falsely signals the preservation of the actual words of a citation when none seems to be present. From a theological point of view, the theme of God's jealousy is linked to the exclusivity of his claims, because he is the only God who is firmly united with his people and who requires fidelity in this relationship, which is expressed repeatedly in the Old Testament through the image of marriage (it appears for the first time in Hosea). Precisely because this God is a personal God, his relationship with the people cannot be dispassionate. He longs for them with jealous longing. To yearn jealously is an echo of the audacious Old Testament anthropomorphism that emerged from the idea of the chosen people of Israel as the bride of their God, who had an exclusive right to their affections and who did not tolerate sharing any of love that belonged to him with the world. We can therefore assume that Jas 4,5b refers to a scriptural theme - God's jealousy. It is not a specific quotation, but it is conceivable that James independently formed this well-known biblical topic about God's jealousy into a quotation. This interpretation corresponds to the way James draws on a rich tradition originating mainly from the Jewish environment.

\section{Conclusion}

The verse Jas 4,5, which undoubtedly belongs to the difficult places in the Letter of James and which was rightly labelled as a crux interpretum, poses two main exegetical problems. On the one hand, it is very difficult to identify the apparent quotation from Scripture, and on the other hand, it is not easy to determine the meaning of this verse as a whole as each expression in it and the general context are the subject of debate. In the Letter of James, we can notice that its author constantly draws ideas, motives, formulation or words from various traditions originating mainly in the 
Jewish environment. This fact is also supported by the verse Jas 4,5, which relates to the theme of fights and quarrels among the members of the Christian community (Jas 4,1-10) and which together with the following verse serves as a justification for the statement about the irreconcilability of friendship with God and friendship with the world (Jas 4,4). Our text starts with a rhetorical question ("Or do you think it is to no purpose that the Scripture says? «, Jas 4,5a) which calls for the recognition of the unconditional validity of what Scripture communicates. Then follows the statement (»He [God] jealously longs for the spirit that he [God] made dwell in us«, Jas 4,5b), which serves as a reminder of God's desire that his people be completely and unconditionally his and provides a fitting justification for warning against flirting with the views and the values of the world in Jas 4,4 . The statement Jas $4,5 \mathrm{~b}$ which is introduced with the formula $\dot{\eta} \gamma$ pa $\phi \dot{\eta}$ $\lambda \varepsilon \dot{\gamma \varepsilon l}$ and which is thus presented as a biblical quotation is not found as a literal quotation in the Old Testament or in the preserved non-biblical writings. We cannot completely rule out the possibility that James quotes an unknown work in Jas 4,5b, but it seems more plausible that he created a scriptural quotation from various elements of Scripture about the theme of God's jealousy, which is connected with the idea of the chosen people of Israel as the bride of their God. He has the sole right to their affections and he does not tolerate sharing any of the love that belongs to him with the world. In conclusion it may be that through a reference to a well-known Old Testament theme, in Jas 4,5b James tries to communicate that God, who gave man the breath of life in creation, longs for him jealously and will not tolerate any »friendship with the world« (Jas 4,4). 


\section{References:}

Adamson, James B. 1976. The Epistle of James. Grand Rapids: Eerdmans.

Aland, Barbara, et al., ed. 2012. Novum Testamentum Graece. Stuttgart: Deutsche Bibelgesellschaft.

- - -. 2014. The Greek New Testament. Stuttgart: Deutsche Bibelgesellschaft.

Alford, Henry. 1864. The Greek Testament, vol. 4. London: Rivingtons.

Allison, jr. Dale C. 2011. Eldad and Modad. JSP 21: 99-131.

- - -. 2013. A critical and exegetical commentary on the Epistle of James. New York: Bloomsbury.

Assaël, Jacqueline - Cuvillier, Élian. 2013. L'Épître de Jacques. Genève: Labor et Fides.

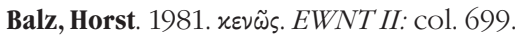

Barth, Markus. 1962. The Old Testament in Hebrews. An Essay in Biblical Hermeneutics. In: William Klassen, Graydon F. Snyder, ed. Issues in New Testament Interpretation, 53-78. London: SCM.

Bauckham, Richard. 1988. James, 1 and 2 Peter, Jude. In: Donald A. Carson - Hugh G. M. Williamson. eds. It Is Written: Scripture Citing Scripture, 303-317. New York: Cambridge University.

- - - 2004. The Spirit of God in Us Loathes Envy: James 4:5. In: Graham N. Stanton, Bruce W. Longenecker, Stephen C. Barton, eds. The Holy Spirit and Christian Origins. 270-281. Grand Rapids: Eerdmans.

Belser, Johannes E. 1909. Die Epistel des heiligen Jakobus. Freiburg im Breisgau: Herdersche Verlagshandlung.

Bengel, Johann A. 1759. Gnomon Novi Testamenti in quo ex nativa verborum vi simplicitas, profunditas, concinnitas, salubritas sensuum coelestium indikatur. Tubingae: Io. Henr. Philippi Schrammii.
Blass, Friedrich - Debrunner, Albert - Rehkopf, Friedrich. 1990. Grammatik des neutestamentlichen Griechisch. Göttingen: Vandenhoeck \& Ruprecht.

Blomberg, Craig L., and Kamell, Mariam J. 2008. James. Grand Rapids: Zondervan.

Bottini, Giovanni C. 1986. Sentenze di Pseudo-Focilide alla luce della lettera di Giacomo. SBFLA 36: 171-181.

- - -. 2014. Lettera di Giacomo. Nuova versione, introduzione e commento. Milano: Paoline.

Brosend II, William F. 2004. James and Jude. Cambridge: University Press.

Burchard, Christoph. 2000. Der Jakobusbrief. Tübingen: Mohr Siebeck.

Burdick, Donald W. 1981. James. In: Frank E. Gaebelein - James D. Douglas, eds. The Expositor's Bible Commentary, Volume 12, 159-205. Grand Rapids: Zondervan.

Cantinat, Jean. 1973. Les Épîtres de Saint Jacques et de Saint Jude. Paris: Gabalda.

Carpenter, Craig B. 2000. James 4.5 Reconsidered. NTS 46: 189-205.

Carson, Donald A. 2007. James. In: Gregory K. Beale, Donald A. Carson, eds. Commentary on the New Testament Use of the Old Testament, 997-1013. Grand Rapids: Baker Academic Nottingham: Apollos.

Chaine, Joseph. 1927. L’Épitre de saint Jacques. Paris: J. Gabalda.

Coppieters, Honoratus. 1915. La Signification et la Provenance de la Citation Jac. iv, 5 . $R B$ 12: 35-58.

Danker, Frederick W., ed. 2000. Greek-English Lexicon of the New Testament and Other Early Christian Literature. Chicago: The University of Chicago Press.

Davids, Peter H. 1982. The Epistle of James. A Commentary on the Greek Text. Exeter: The Paternoster Press. 
De Ambroggi, Pietro. 1949. Le epistole Cattoliche di Giacomo, Pietro, Giovanni e Giuda. Torino, Roma: Marietti.

DeSilva, David A. 2012. The Jewish Teachers of Jesus, James, and Jude: What Earliest Christianity Learned from the Apocrypha and Pseudepigrapha. Oxford: University Press.

Dibelius, Martin. 1984. Der Brief des Jakobus Göttingen: Vandenhoeck \& Ruprecht.

Ewald, Heinrich. 1870. Das Sendschreiben an die Hebräer und Jakobos' Rundschreiben. Göttingen: Dieterichschen Buchhandlung.

Fabris, Rinaldo. 2004. Lettera di Giacomo. Introduzione, versione, commento. Bologna: EDB.

Farley, Lawrence R. 2008. Universal Truth. The Catholic Epistles of James, Peter, Jude, and John. Ben Lomond: Conciliar Press.

Findlay, J. A. 1925-1926. James IV. 5,6. ET 37: 381-382.

Forster, A. Haire. 1917-1918. James IV. 5,6. ET 29: 139.

Frankemölle, Hubert. 1994. Der Brief des Jakobus, I-II. Gütersloh: Gerd Mohn.

Gebser, August R. 1828. Der Brief des Jakobus, mit genauer Berücksichtigung der alten griechischen und lateinischen Ausleger. Berlin: August Rücker.

Grimm, Wilibald D. 1854. Ueber die Stelle Br. Jakobi IV. V. 5. und 6a. ThStKr 27: 934-956.

Grünzweig, Fritz. 1973. Der Brief des Jakobus. Wuppertal: Rolf Brockhaus.

Hagner, Donald A. 2012. The New Testament. A Historical and Theological Introduction. Grand Rapids: Baker Academic.

Halson, Bruce R. 1968. Epistle of James: 'Christian Wisdom?'. In: Frank L. Cross, ed. Studia Evangelica IV/1, 308-314. Berlin: Akademie Verlag.

Hanson, Anthony T. 1983. The Living Utterances of God. The New Testament Exegesis of the Old. London: Darton, Longman and Todd.

Hartin, Patrick J. 2003. James. Collegeville: Liturgical Press.
Hauck, Friedrich. 1926. Der Brief des Jakobus. Leipzig: A. Deichertsche Verlagsbuchhandlung.

Hauck, Friedrich. 1947. Die Briefe des Jakobus, Petrus, Judas und Johannes. Göttingen: Vandenhoeck \& Ruprecht.

Heckel, Theo K. 2019. Die Briefe des Jakobus, Petrus, Johannes und Judas. Göttingen: Vandenhoeck \& Ruprecht.

Hoppe, Rudolf. 1977. Der theologische Hintergrund des Jakobusbriefes. Würzburg: Echter.

- - -. 1989. Jakobusbrief. Stuttgart: Katholische Bibelwerk.

Hort, Fenton J. A. 1909. The Epistle of St. James: The Greek Text with Introduction, Commentary as Far as Chapter IV, Verse 7, and Additional Notes. London: Macmillan.

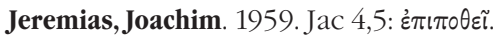
ZNW 50: 137-138.

Johnson, Luke T. 1982. The Use of Leviticus 19 in the Letter of James. $J B L 101$ : 391-401.

- - -. 1983. James 3:13-4:10 and the Topos $\pi \varepsilon \rho ı$ фovou. NT 25: 327-347.

- - -. 1995. The Letter of James. A New Translation with Introduction and Commentary. New York: Doubleday.

Kirn, Otto. 1904. Ein Vorschlag zu Jakobus 4,5. ThStKr 77: 127-133.

- - -. 1904. Noch einmal Jakobus 4,5. ThStKr 77: 593-604.

Klein, Martin. 1995. Ein vollkommenes Werk. Vollkommenheit, Gesetz und Gericht als theologische Themen des Jakobusbriefes. Stuttgart - Berlin Köln: Kohlhammer.

Kloppenborg, John S. 2004. The Reception of the Jesus Tradition in James. In: Jacques Schlosser, ed. The Catholic Epistles and the Tradition, 93-141. Leuven: University Press, 2004.

Könnecke, Clemens. 1908. Emendationen zu Stellen des Neuen Testaments. Gütersloh: Bertelsmann.

Konradt, Matthias. 1998. Christliche Existenz nach dem Jakobusbrief. Eine Studie zu seiner soteriologischen und ethischen Konzeption. Göttingen: Vandenhoeck \& Ruprecht. 
Kugelman, Richard. 1980. James E Jude. Wilmington: Michael Glazier.

Laws, Sophie S. 1973. Does Scripture Speak in Vain? A Reconsideration of James IV. 5. NTS 20: 210-215.

- - -. 1980. A Commentary on the Epistle of James. London: Adam \& Charles Black.

Von Lips, Hermann. 1990. Weisheitliche Traditionen im Neuen Testament. Neukirchen-Vluyn: Neukirchener.

Maier, Gerhard. 2004. Der Brief des Jakobus. Wuppertal: R. Brockhaus - Gießen: Brunnen.

Malherbe, Abraham J. 1992. Hellenistic Moralists and the New Testament. In: Wolfgang Haase, Hildegard Temporini, ed. Aufstieg und Niedergang der römischen Welt II 26,1, 267-333. Berlin, New York: Walter de Gruyter.

Martin, Ralph P. 1988. James. Waco: Word Book.

Marty, Jacques. 1935. L'Épître de Jacques. Paris: Alcan.

Mayor, Joseph B. 1892. The Epistle of St.James: The Greek Text with Introduction, Notes and Comments. London: Macmillan.

McCartney, Dan G. 2009. James. Grand Rapids: Baker Academic.

McKnight, Scot. 2011. The Letter of James. Grand Rapids: Eerdmans.

Metzger, Bruce M. 2000. A Textual Commentary on the Greek New Testament. Stuttgart: Deutsche Bibelgesellschaft.

Metzner, Rainer. 2017. Der Brief des Jakobus. Leipzig: Evangelische Verlagsanstalt.

Meyer, Arnold. 1930. Das Rätsel des Jacobusbriefes. Gießen: Töpelmann.

Michl, Johann. 1963. Der Spruch Jakobusbrief 4,5. In: Josef Blinzler, Otto Kuss, Franz Mußner, ed. Neutestamentliche Aufsätze, 167-174. Regensburg: Pustet.

- - -. 1968. Die katholischen Briefe. Regensburg: Friedrich Pustet.

Mitton, C. Leslie. 1966. The Epistle of James. London: Marshall, Morgan \& Scott.
Moffatt, James. 1953. The General Epistles James, Peter, and Judas. London: Hodder and Stoughton.

Moo, Douglas J. 2009. James. An Introduction and Commentary. Nottingham Downers Grove: Inter-Varsity Press.

Mußner, Franz. 1987. Der Jakobusbrief. Basel, Freiburg, Wien: Herder.

Nystrom, David P. 1997. James. Grand Rapids: Zondervan.

Painter, John. 2012. James. In: John Painter, David A. deSilva, ed. James and Jude, 1-174. Grand Rapids: Baker Academic, 2012.

Penner, Todd C. 1996. The Epistle of James and Eschatology. Re-reading an Ancient Christian Letter. Sheffield: Academic Press.

Peterson, Erik. 1923. Der Gottesfreund. Beiträge zur Geschichte eines religiösen Terminus. ZKG 42:161-202.

Plumptre, Edward H. 1909. The General Epistle of St. James. Cambridge: University Press.

Popkes, Wiard. 1997. The Composition of James and Intertextuality. An Exercise in Methodology. StTh 51: 99-112.

- - -. 1999. James and Scripture. An Exercise in Intertextuality. NTS 45: 213-229.

- - -. 2001. Der Brief des Jakobus. Leipzig: Evangelische Verlagsanstalt.

- - -. 2004. Traditionen und Traditionsbrüche im Jakobusbrief. In: Jacques Schlosser, ed. The Catholic Epistles and the Tradition, 143-170. Leuven: Leuven University Press.

Prockter, Lewis J. 1989. James 4. 4-6: Midrash on Noah. NTS 35: 625-627.

Reicke, Bo. 1964. The Epistle of James, Peter, and Jude. Garden City: Doubleday.

Richardson, Kurt A. 1997. James. Nashville: B\&H Publishing Group.

Ropes, James H. 1916. A Critical and Exegetical Commentary on the Epistle of St. James. Edinburgh: T. \& T. Clark.

Ruckstuhl, Eugen. 1988. Jakobusbrief; 1.-3. Johannesbrief. Würzburg: Echter.

Schlatter, Adolf. 1932. Der Brief des Jakobus. Stuttgart: Calwer Vereinsbuchhandlung. 
Schneckenburger, Matthias. 1832. Annotatio ad Epistolam Jacobi perpetua cum brevi tractatione isagogica. Stuttgart: F. C. Loeflund.

Schneider, Johannes. 1961. Die Briefe des Jakobus, Petrus, Judas und Johannes. Die Katholischen Briefe. Göttingen: Vandenhoeck \& Ruprecht.

Schnelle, Udo. 2002. Einleitung in das Neue Testament. Göttingen: Vandenhoeck \& Ruprecht.

Schnider, Franz. 1987. Der Jakobusbrief. Regensburg: Friedrich Pustet.

Schrage, Wolfgang. 1993. Der Jakobusbrief. In: Horst Balz, Wolfgang Schrage, ed. Die "Katholischen «Briefe. Die Briefe des Jakobus, Petrus, Johannes und Judas, 5-59. Göttingen: Vandenhoeck \& Ruprecht.

Schröter, Jens. 2008. Jesus Tradition in Matthew, James, and the Didache. Searching for Characteristic Emphases. In: Huub van de Sandt, Jürgen K. Zangenberg, ed. Matthew, James, and Didache. Three Related Documents in Their Jewish and Christian Settings, 233-255. Leiden, Boston: Brill.

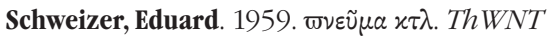
6: 387-453.

Sidebottom, Ernest M. 1967. James, Jude and 2 Peter. London: Thomas Nelson.

Sleeper, C. Freeman. 1998. James. Nashville: Abingdon.

Spicq, Ceslas. 1991. Lexique théologique du Nouveau Testament. Fribourg: Cerf.

Spitta, Friedrich. 1896. Zur Geschichte und Literatur des Urchristentum. Bd. II: Der Brief des Jakobus. Studien zum Hirten des Hermas. Göttingen: Vandenhoeck \& Ruprecht.

Stählin, Gustav. 1973. фí $\lambda \circ \kappa \kappa \tau \lambda$. ThWNT IX: 144-169.
Tasker, Randolph V. G. 1956. The General Epistle of James. An Introduction and Commentary. London: Tyndale Press.

Tsuji, Manabu. 1997. Glaube zwischen Vollkommenheit und Verweltlichung. Eine Untersuchung zur literarischen Gestalt und zur inhaltlichen Kohärenz des Jakobusbriefes. Tübingen: J. C. B. Mohr (Paul Siebeck).

Varner, William. 2014. James. Bellingham, WA: Lexham.

Verseput, Donald J. 1998. Wisdom, 4Q185, and Epistle of James. JBL 117: 691-707.

Vouga, François. 1984. L'Épître de Saint Jacques. Genève: Labor et Fides.

Wall, Robert W. 1997. Community of the Wise. The Letter of James. Valley Forge: Trinity Press International.

De Wette, Wilhelm Martin Leberecht. 1853. Erklärung der Briefe des Petrus Judas und Jakobus. Leipzig: S. Hirzel.

Wettlaufer, Ryan D. 2013. James 4:5. No Longer Written: The Use of Conjectural Emendation in the Restoration of the Text of the New Testament, the Epistle of James as a Case Study, 125-157. Leiden, Boston: Brill.

Wettstein, Johann Jakob. 1730. Prolegomena ad Novi Testamenti Graeci editionem accuratissimam. Amstelaedami: Apud R. \& J. Wetstenios \& G. Smith.

Windisch, Hans - Preisker, Herbert. 1951. Die katholischen Briefe. Tübingen: J. C. B. Mohr.

Witherington III, Ben. 2007. Letters and Homilies for Jewish Christians. A SocioRhetorical Commentary on Hebrews, James and Jude. Downers Grove, Nottingham: IVP.

Wypadlo, Adrian. 2006. Viel vermag das inständige Gebet eines Gerechten (Jak 5,16). Die Weisung zum Gebet im Jakobusbrief. Würzburg: Echter. 